\title{
GEOMORFOLOŠKI RAZVOJ DOLINE KRNICE IN NJENE ZADNJE POLEDENITVE
}

\author{
Jurij Kunaver*
}

Izvleček

UDK 911.2:551.32(234.3 Julijske Alpe)

Prispevek obravnava geomorfološki razvoj doline Krnice pri Kranjski gori, ki po nastanku spominja na podoben razvoj na območju Vršiča. Tudi tu gre za prevladujoče apnenčaste skladovnice $v$ vrhnjih delih gora oziroma gorskih obodov, medtem ko so spodnji deli pobočj pretežno zgrajeni iz dolomita. Ob upoštevanju selektivne erozije sta si tako zareza Vršiča kot tudi dolina Krnice genetsko podobna, še zlasti zaradi poteka močnih prelomov čez obe območji. Krnica se je pokazala kot predel najpomembnejše poledenitve $v$ tej pokrajini, čemur bi bilo mogoče pripisati tudi nastanek poznoglacialnih morenskih nasipov med Eriko in Kranjsko goro.

Ključne besede: Julijske Alpe, selektivna erozija, dolomit, prelomna cona, postwürmska stadialna poledenitev

GEOMORPHOLOGICAL DEVELOPMENT OF THE KRNICA VALLEY AND ITS LATE GLACIATION

\section{Abstract}

The paper deals with the geomorphological development of the elongated Krnica valley in the Julian Alps near Kranjska gora, which geneticaly resembles to the Vršič Pass. The basic idea is the development of this Alpine valley under the strong influence of the softer dolomitic strata which is beneath the limestone. Besides, the fault lines contribute a lot to this development. Not only the frontal moraines in the valley itself but also the two of them near Kranjska gora can be the result of the same late postwürmian stadial glacier, as this was the longest in the region.

Key words: Julian Alps, selective erosion, dolomite, fault line zone, late stadial glaciation

\footnotetext{
* Dr., univ. prof., Oddelek za geografijo Filozofska fakulteta, Univerza v Ljubljani, Aškerčeva cesta 2, 1000 Ljubljana
} 


\section{UVOD}

V zadnjih letih je bilo napisano več razprav o geomorfološki in fizičnogeografski podobi stranskih dolin $\mathrm{v}$ Zgornjesavski dolini, zlasti o dolini Tamarja. S področja geomorfologije sta pomembni razpravi I. Gamsa o mladokvartarni geomorfologiji Tamarja in Zgornjesavske doline (1992) in J. Kunaverja o geomorfologiji Vršiča (1992). Pričujoče besedilo obravnava geomorfološke razmere na območju doline Krnice, nedaleč od Vršiča, ki doslej geomorfološko še ni bila obdelana, a je pomembna za razumevanje razvoja nekaterih naših, zlasti sosednjih alpskih dolin. Zadeva pa tudi širšo problematiko razvoja poznopleistocenske poledenitve $v$ Julijskih Alpah sploh. To je prispevek k sistematičnemu geomorfološkemu pregledu širše okolice Kranjske gore oziroma Zgornjesavske doline, ki je že doslej bila predmet raziskovanja razmeroma številnih avtorjev.

\section{TEKTONSKA IN LITOLOŠKA ZASNOVANOST VISOKOGORSKEGA STRUKTURNEGA RELIEFA}

Geologija območja Vršiča je bila že doslej precej temeljito predstavljena, zato tu le nekaj poudarkov v zvezi s pomenom za razvoj reliefa. Za njegovo širšo okolico so značilne kamnine od perma do zgornjega triasa, pri čemur prevladujejo zgornjetriasni apnenci in drobljivi srednjetriasni anizijski dolomit. V slednjem sta denudacija in erozija vzdolž mojstrovške dislokacije ustvarili poleg dolin Velike in Male Pišnice predvsem globoko zajedo Vršiča. Iz zgornjetriasnih apnencov so zgrajeni značilni priostreni vrhovi kot posledica selektivne erozije in luskaste tektonske zgradbe.

Nastanek prevala Vršiča, ki je v vrhnjem delu v glavnem zgrajen iz srednjetriasnega anizijskega dolomita, v starejši literaturi povezujejo z rečnim tokom (Melik, 1954), ki naj bi bil nekdaj usmerjen od juga, iz Zgornje Trente proti severu čez Karavanke. To veliko dolinsko vrzel, ki je prekinila enoten greben v tem delu Julijskih Alp in se zajedla med Prisank in Mojstrovko tako s soške kot tudi pišenske strani, pa je mogoče pripisati tudi selektivni eroziji, ki je posledica slabše odpornosti dolomita. Postavljena je bila domneva, da je nekoč tudi prek Vršiča segal apnenčast pokrov, ki pa sta ga pospešena denudacija in erozija zadenjsko odstranili zaradi manj odporne dolomitne podlage. Vršič zato po nastanku, kljub svoji širini, spominja na nekatere druge škrbine in sedla, npr. na Prevalo v Kaninskem pogorju, pod katero je podobno razgaljena dolomitna podlaga (Kunaver, 1983, 222-223; Kunaver, 1991, 84, glej geološki prerez Vršiča). 
Vršiški anizijski dolomitnoapnenčasti pas se po geološki karti nadaljuje še proti severovzhodu in gradi obe pobočji doline Velike Pišnice skoraj do Kranjske gore, najdemo pa ga tudi $v$ spodnjem delu pobočij gorskega venca okrog in okrog nad dolino Krnice. Tudi spodnji del doline Male Pišence je izrazito dolomiten, a naj bi bil karnijske starosti. Dolomitni značaj dokazujejo številni ošiljeni vrhovi in erozijsko oziroma hudourniško razdrapana pobočja na obeh straneh doline Velike Pišnice med Klinom in Jasno, zlasti pa spodnji del doline Male Pišnice. Značilen je tudi vpliv take geološke zgradbe na geomorfološke razmere v dolini Krnice. Vsi nižji deli njenih zahodnih pobočij s podnožjem vred, t.j. pod Goličico, Prisojnikom, zadnjim Prisojnikom, Razorjem do Kriške stene, in tudi spodnji deli jugovzhodnih pobočij pod Dovškim Gamsovcem, Dolkovo Špico in Škrlatico, so zgrajeni iz dolomita. Litološka meja poteka na višini med 1700 in $1800 \mathrm{~m}$ in je jasno vidna tako zaradi morfološke in vegetacijske spremembe, to je zaradi prehoda iz položnejših, $z$ rušjem poraščenih in $z$ erozijskimi grapami razdrapanih dolomitnih pobočij $\mathrm{v}$ gola prepadna apnenčasta ostenja ( sl.1).

Na tej litološki meji tik pod stenami molijo ven iz pobočij krajši pomoli, zgrajeni že iz dolomita. Pomoli so posledica menjave med erozijsko in denudacijsko bolj poglobljenimi deli ostenij, torej grapami in vmesnimi, od zunanjih sil manj prizadetimi območji. Takih pomolov je več in imajo tudi značilna imena, npr. $1765 \mathrm{~m}$ visoki obsežni pomol Zadnja glava pod Zadnjim Prisojnikom, ter več pomolov na vzhodnih pobočjih kot npr. Mizica in Grunt. Take pomole vidimo tudi ponekod drugod v Julijcih, npr. pod Loško steno v dolini Koritnice. Posledica omenjene zgradbe so tudi nekatere manjše krnice v pravkar omenjenem ostenju, a tudi dve veliki krnici na vzhodnih pobočjih Prisojnika oziroma Malega Prisojnika imata bržkone osnovo $\mathrm{v}$ hitrejšem preperevanju dolomitne podlage (glej geomorfološko karto).

Tudi mnoge druge naše stene, ki so večinoma posledica luskaste tektonske zgradbe in iz tega izvirajoče geološke in morfološke nesimetričnosti prečnih profilov dolin, oziroma neskladnosti med vpadom skladov in potekom pobočij, imajo v spodnjem delu dolomit, vrhnji pa je iz apnenca. Ne glede na starost apnenca in dolomita $\mathrm{v}$ stenah se mehansko obe kamnini vedno obnašata različno. Skupaj pa ustvarjata genetsko in morfološko podoben tip pobočnega reliefa, ki je zlasti značilen za severni del Julijskih Alp.

\section{NASTANEK IN RAZVOJ DOLINE KRNICE}

Dolina Krnice ima presenetljivo premočrten potek, kar je mogoče razložiti z navezanostjo na dinarsko potekajoči prelom oziroma prelomno območje, ki ima svoje 
nadaljevanje tako v severozahodni kot tudi v jugovzhodni smeri. A v sosedstvu, razen $\mathrm{v}$ Trenti, ni podobno usmerjenih dolin. To prelomno območje, ki jo označuje izrazita dislokacija, je na terenu najbolj jasno mogoče videti v sredini Kriške stene (sl. 2). Po geološki karti je zahodna stran zgrajena iz karnijskega masivnega in skladnatega dolomita in apnenca, vzhodna pa iz anizijsko-ladinijskega skladnatega dolomita in apnenca. Zahodna stran je torej dvignjena, kar se ujema z mnenjem S. Buserja (ustno) o močni tektonski dvignjenosti Prisojnikovega bloka oziroma tega dela Julijskih Alp (Kunaver, 1992, 84). Zanimivo je, da tudi Gams omenja "več prelomnic severno od jezera pod Križem v pobočju Kriškega roba, ki se nadaljujejo v jezersko kotanjo" (1962, 236).

Pri razlagi nastanka doline Krnice si lahko pomagamo z že omenjeno litološko zgradbo, saj ne more biti dvoma, da sta mehkejša dolomitna podlaga in omenjeni prelom izdatno pomagala pri izdolbljenju celotne doline. Končni, najdlje umaknjeni dolinski zatrep pod Kriško steno, širok največ $200 \mathrm{~m}$, je natančno v osi današnje doline. Na območju koče v Krnici in pod njo je dolina široka približno $500 \mathrm{~m}$ in se od tam, predvsem v smeri Kriške stene, postopoma oži in izdatneje dviga. V najvišjem delu, nad $1650 \mathrm{~m}$, je najizrazitejši dolinski skok, v katerem se dno doline dvigne v zadnji, razmeroma uravnani in najožji del med 1800 in 1900 m nadmorske višine. Ker se okoliške stene tu že neposredno spuščajo do dna, dajejo zatrepu videz nekakšnega kanjona. V postopnem oženju in dviganju doline se kažejo postopnost njenega razvoja in različna intenzivnost, trajanje in vrsta geomorfoloških procesov.

Domnevamo, da je dno zaključne krnice pod Kriško steno zelo blizu litološke meje, oziroma da je na oblikovanje tega dela doline Krnice (in tudi spodnjega dela doline) imela predvsem dolomitna podlaga močan vpliv. Na dolomitni podlagi se namreč lahko ustvarijo površinsko tekoči vodni tokovi (lahko tudi podzemeljski vodni tokovi), s tem pa je omogočeno tudi izdatnejše izvotljenje kraškega podzemlja in rušenje apnenčastega pokrova. Razmeroma visoka lega dolomitne podlage morda vpliva tudi na pojav površinske vode oziroma jezer v ledeniškokraških kotanjah na Kriških podih, kar bi bila nekoliko drugačna razlaga tega pojava od dosedanje (Gams, 1962).

V dolini Krnice in v Kriški steni, ki je znižan del sosednjih ostenij, vidimo zato podoben pojav, kakršen se kaže na Vršiču. Z nadaljnjim umikanjem Kriške stene bo počasi prišlo do razpada apnenčastega pokrova in do nastanka Vršiču podobne vrzeli oziroma prevala. Podoben proces poteka v neposredni soseščini, v veliki krnici na severovzhodni strani pod Škrbino v Mlinarici. Tudi tu se gorski greben hitreje tanjša in umika kot v soseščini in to z obeh, mlinariške in krniške strani, saj je Škrbina (1995 m) že vsaj $200 \mathrm{~m}$ nižja od sosedstva. Vse to kaže, da primer Vršiča v osrednjih Julijskih Alpah ni osamljen in da je v uvodu omenjena razlaga njegovega nastanka $\mathrm{s}$ tem še bolj podprta. O močni razkosanosti s prelomi tega območja piše tudi A. Ramovš, zlasti o Razorju, katerega vrh, ki "je zgrajen iz lahno nagnjenih skladov 
dachsteinskega apnenca...oziroma masivnega apnenca...je razklan z navpičnimi in poševnimi prelomi" (1983, 326).

\section{POZNOGLACIALNA POLEDENITEV DOLINE KRNICE}

Dolina Krnice je v primerjavi s sosednjimi stranskimi dolinami nekoliko hvaležnejša za raziskovanje sledov poznoglacialne poledenitve, ker so razmeroma pogostejši in so dovolj dobro ohranjeni. Doslej je bila s tega vidika podrobneje obdelana le dolina Planice, kjer je poseben problem "edinstvena sredinska morena $\mathrm{v}$ dolinah Julijskih Alp" v obliki neobičajnega "dobra dva kilometra" dolgega podolgovatega morenskega nasipa (Gams, 1992, 16-17). Opisani pa so bili tudi poznoglacialni zastoji in njihove morene na obeh straneh Vršiča (Kunaver, 1990, 88-89).

Gams ugotavlja, da bi od stadialne poledenitve, ko naj bi se planiški ledenik umikal po dolini navzgor, morali ostati stadialni morenski venci, izbočeni proti severu. A teh in takih ni. Zato je vrh sredinske morene lahko nastal le s padanjem podornega skalovja in grušča na dno doline $\mathrm{z}$ obeh pobočij, ko so do dna še segala trajna snežišča. Gams na podlagi tega domneva, da ledenik, če je takrat še bil v dnu doline, ni imel take sposobnosti prenašanja gradiva, kot se to navadno predvideva. Tudi morenski nasipi pri Kamnu pod Ratečami naj bi zato ne bili rezultat poznoglacialnega planiškega ledenika. Stranskim alpskim dolinam tega območja torej na splošno ne pripisuje "sposobnost tvorbe večjih ledenih gmot in prenašanja morenskega gradiva, saj naj bi jih zajezeval dolinski ledenik" (Gams, 1992, 45). To naj bi veljalo zlasti za dolino Planice in Krme, manj pa za dolino Male Pišnice, Martuljkovo skupino in Kot.

Zajezitev te vrste v dolini Krnice, ki je Gams sicer ne omenja, glede na tamkajšnje stanje ni verjetno. Sicer pa je že sama obilnost poznoglacialnega morenskega gradiva v dolini sama po sebi dokaz, da je bila poledenitev v vsaki pleistocenski ohladitvi tu precej izdatna. Na to kaže med drugim tudi videz same doline (sl. 3). Dvomljivo je, da na višku poledenitve sploh lahko prišlo do zajezevanja, saj so imeli stranski ledeniki zadosten dotok ledu in večji višinski gradient kot pa dolinski ledenik. Sicer pa je o "zajezevanju" pri gibanju ledeniških mas na splošno težko govoriti. Nadaljna razprava o obsegu in učinkih poledenitev $v$ naših Alpah se bo morda $v$ prihodnosti lažje opredelila za eno ali druga stališče, zlasti če bi bilo še več sistematičnega geomorfološkega raziskovanja.

Mnenja smo tudi, da je treba jasneje ločiti med dogajanjem ob višku poledenitve in tistim $\mathrm{v}$ postwürmskem oziroma poznoglacialnem obdobju, ko je prišlo do samostojnih stadialnih poledenitvenih sunkov (Kunaver, 1990, 213). Takrat pa 
zgornjesavskega dolinskega ledenika, ki se je na višku ohladitev hranil tudi iz Ziljske doline, bržkone ni bilo več.

Poznoglacialno morensko gradivo je od stika $\mathrm{z}$ dolino Velike Pišnice pri Malem Tamarju do Kriške stene odloženo v večjih količinah kar na štirih krajih. To kaže na postopno zmanjševanje ledeniškega stanja ob koncu würma, kar je mogoče primerjati z mnogimi drugimi dolinami v Julijcih, zlasti višje ležečimi (Kunaver, 1990). Prvič najdemo večje količine morenskega gradiva $\mathrm{v}$ obliki na gosto posuth apnenčastih balvanov in ozkega, skoraj $500 \mathrm{~m}$ dolgega dvignjenega morenskega hrbta, vzporednega $\mathrm{z}$ osjo doline, $\mathrm{v}$ območju med Malim Tamarjem in kočo v Krnici, na višini od 1000 do $1050 \mathrm{~m}$. Taka smer nasipa spominja na podoben pojav v Planici. Ledenik je bila takrat dolg približno 3 kilometre.

Isti ledenik bi lahko segal celo dlje, saj so naslednje nižje čelne morene na vzpetini Žaga (956 m) tik nad cesto med hotelom Erika in Jasno, ki jih omenja tudi Gams $(1992,31)$. V tem primeru bi bil poznoglacialni krniški ledenik še za tri kilometre daljši.

Naslednji zastoj je nad kočo $\mathrm{v}$ Krnici in ga predstavlja značilno podolgovat in $\mathrm{z}$ balvani na gosto posut morenski nasip, ki se vleče od nekako $1200 \mathrm{~m}$ do $1300 \mathrm{~m}$ nadmorske višine $\mathrm{v}$ dolžini skoraj $700 \mathrm{~m}$. Odložen je bil $\mathrm{v}$ osi doline, torej $\mathrm{v}$ smeri gibanja ledu, in ne prečno, kot bi pričakovali. Zato ga je mogoče primerjati z morenskim nasipom v dolini Planice, čeprav je tako po višini kot po širini bistveno manjši. I. Gams je planiško moreno imenoval "sredinska", kar spominja na "srednjo" moreno $\mathrm{v}$ gibajočem se dolinskem ledeniku. Ker oba pojava nista genetsko povsem enaka, oziroma je planiški primer precej specifičen, se zdi tako poimenovanje nekoliko sporno.

Tretji ledeniški zastoj na višini $1800 \mathrm{~m}$ je rezultat še krajšega ledenika, ki je zapolnjeval

najvišji del krniške doline in je verjetno meril vsega slab kilometer. Zapustil je dva značilna dolga vzporedna bočna morenska nasipa, ki pokrivata strmo stopnjo pred zaključno krnico in segata od 1450 do $1650 \mathrm{~m}$ visoko. Čelnega nasipa ni videti, kar je znak, da ga je ledeniška voda odstranila, to pa potrjuje precej poglobljena grapa med obema nasipoma. $\mathrm{V}$ zadnjem obdobju obstoja ledenika se je ta zadrževal tik pod Kriško steno na višini okrog 1900 m, kjer je ustvaril dve zaporedni čelni moreni.

Po številu in višinski razporeditvi ledeniških zastojev je dolino Krnice mogoče primerjati z nekaterimi dolinami na soški strani, npr. z dolino Bale in Bavšice, še lažje pa s trentarskimi dolinami. Glede na izrazitost ledeniških sledov je savska stran videti revnejša od soške, kar je morda posledica obilnejših padavin in izdatnejše poledenitve v Posoških Julijskih Alpah. Zato je upravičeno mogoče predpostavljati, da so na obeh straneh Julijcev hkrati obstajali različno dolgi poznoglacialni ledeniki. Lahko pa bi se 
tudi pokazalo, da sta čelni moreni Žaga in celo čelna morena pri Jasni, južno od Kranjske gore, ki ju Gams omenja v drugačni zvezi ( glej sliko 6, Gams, 1992, 32), delo istega, torej krniškega ledenika. Ta je $\mathrm{v}$ najzgodnejšem postglacialu moral biti okrepljen tudi z ledom z vršiške strani. V tem primeru bi bilo mogoče govoriti celo o bühlskem stadiju pri Jasni oziroma pri Žagi. Na terenskih vajah s študenti geografije smo si vzpetino Žaga v spodnjem delu doline Velike Pišnice, tik nad Jasno, tudi podrobneje ogledali. Navidez je $\mathrm{v}$ celoti morenska, a podlaga je neizpodbitno živoskalna. Le vrhnji del je obsut $\mathrm{z}$ morenskim gradivom in zato spominja na čelni morenski nasip.

Če bühlskega stadija $v$ tem trenutku še ni mogoče povsem neizpodbitno jasno dokazati, ker so potrebne še dodatne raziskave, ne more biti dvoma, da so morenski nasipi v dolini Krnice rezultat poledenitvenih stadijev srednjega in najmlajšega končnega poznoglacialnega obdobja.

\section{SKLEP}

Nastanek doline Krnice je mogoče primerjati z Vršičem zaradi selektivne erozije v slabše odpornem dolomitu. Vršiški anizijsko-ladinijski dolomitno apnenčasti pas najdemo zastopan tudi v Krnici, predvsem v spodnjem delu pobočij gorskega venca okrog in okrog Krnice. Na litološki meji tik pod stenami so se izoblikovali značilni dolomitni pomoli, do tja pa sega tudi poraščenost. Za nastanek in usmerjenost Krnice je pomemben dinarsko potekajoč prelomni pas z dislokacijo, ki je posebej jasno vidna v Kriški steni. Dolina je nastala tako z erozijskim poglabljanjem prelomnega pasu kot tudi zaradi razpadanja apnenčevega pokrova nad dolomitno podlago. Ta proces še traja in v prihodnosti je mogoče predvidevati nastanek Vršiču podobnega dolomitnega prevala tam, kjer je danes Kriška stena. V dolini Krnice je poznoglacialno morensko gradivo odloženo na štirih krajih, kar kaže na enako število poznoglacialnih umikalnih stadijev. Če bi se pokazalo, da je poznoglacialni krniški ledenik, kot največji in najpomembnejši v tem območju, ustvaril tudi morenske nasipe pri Žagi, južno od Jasne in celo nasipe pri Jasni sami, ki so po starosti lahko bühlski, je dana dobra podlaga za primerjavo poznoglacialnega razvoja na savski in soški strani glavnega grebena Julijcev. 


\section{LITERATURA IN VIRI:}

1. Gams I., 1962: Visokogorska jezera v Sloveniji. Gradivo. Geografski zbornik, VII, 1962. Ljubljana.

2. Gams I., 1992: Prispevek k mladokvartarni geomorfologiji v Zgornjesavski dolini. Acta geographica, XXXII, 1992. ZRC-SAZU, razred za naravoslovne vede.

3. Jurkovšek B. et al., 1987: Osnovna geološka karta SFRJ, Beljak in Ponteba, 1:100.000. Beograd.

4. Jurkovšek B. et al., 1987: Tolmač listov Beljak in Ponteba. Osnovna geološka karta 1:100.000. Beograd.

5. Kunaver J., 1980: Razvoj in sledovi zadnje stadialne poledenitve v Zgornjem Posočju(I). Geografski vestnik, LII (1980). Ljubljana.

6. Kunaver J., 1983: Geomorfološki razvoj Kaninskega pogorja s posebnim ozirom na glaciokraške pojave. Geografski zbornik, XXII/4, 1982. Ljubljana.

7. Kunaver J., 1990: Poznoglacialne morene v najvišjih delih Posoških Julijskih Alp in poskus njihove datacije. Geomorfologija in geoekologija, 5. znanstveno posvetovanje geomorfologov Jugoslavije. Krško, 18.-23. junij 1990. Zbornik referatov. Ljubljana.

8. Kunaver J., 1991: H geomorfologiji dolomitnega prevala Vršič v Julijskih Alpah. Geografski vestnik LXII, 1991. Ljubljana.

9. Lovrenčak F., 1987: Zgornja gozdna meja v Julijskih Alpah in na visokih kraških planotah Slovenije. Geografski zbornik, XXVI, 1986, SAZU. Ljubljana.

10. Melik A., 1954: Slovenski alpski svet. Slovenija. Slovenska matica. Ljubljana.

11. Pintar J., 1977: Metodološka zasnova analize povirij voda s primerjalno presojo

12. Primernosti površin za smučišča v povirju Pišence. Cipra, Bovec 1977. Podjetje za urejanje hudournikov. Ljubljana.

13. Ramovš A., 1976: Geološki sprehod po severozahodnem ostenju Prisojnika. Proteus 39, 1976/77, 3. Ljubljana. Str.117-121 .

14. Ramovš A., 1983: Na Razor, geološko najzanimivejšo goro v Julijcih. Proteus, L. 45 (1982-1983), maj-junij 1983. Ljubljana.

15. Ramovš A., 1985: Iz geološke zgodovine TNP. Triglavski narodni park. Vodnik. Triglavski narodni park. Bled.

16. Vodnogospodarska ureditev povirja Pišence: Vodnogospodarski inštitut, vodnogospodarski oddelek. Ljubljana 1987. 


\title{
GEOMORPHOLOGICAL DEVELOPMENT OF THE KRNICA VALLEY AND ITS LATE GLACIATION
}

\begin{abstract}
Summary
The origin of the Krnica valley, located in the drainage basin of Velika Pišnica to the south of Vršič Pass in Julian Alps, is supposed to be similar to the Vršič Pass itself. The whole bottom of the valley is composed of Anisian dolomite of the Middle Triasic age which in the altitude of about $1800 \mathrm{~m}$ sharply transforms into the upper Triasic limestone. According to this, the less inclined scarp dolomitic slopes are covered with the dispersed are without it. Due to differential erosion of the dolomitic slopes in the upper part of the dolomitic slopes a number of balconies developed.

The origin of the straightforward course of the valley is directly linked with the Dinaric oriented normal fault line which is clearly visible on its uppermost part in the wall of the Kriška stena (stena=wall). The valley itself is the result of the erosion along this fault line zone but the dolomite also contributed a lot in acceleration of this process. We even suppose that the process of deepening of the valley, as well as of the lowering of the main ridge, resembles very much the situation at the Vršič pass. Therefore the idea of the limestone cover, which had been rather quickly destroyed and removed from the area of Vršič because of the less resistant dolomitic zone beneath and because of the Mojstrovka fault line, could also be useful at this case.

The valley of Krnica is rather rich in glacial material of the late and post Würmian glaciations. Four morainic accumulations, deposited in the lenght of three kilometers between 1000 and 1900 meters, could be compared to the accumulations in upper reaches of many other Julian Alps' valleys. Another two frontal moraines are located at the end of the valley of Velika Pišnica, not far from Kranjska gora. In case of proving their earliest postglacial age, namely of the Bühl stadium, it is obvious that the Krnica glacier was mainly responsible for their origin, too. In such a case the glaciation of this valley is directly comparable with some valleys in the Upper Soča valley where the development of the postwürmian glaciations was quite expressive.
\end{abstract}




\section{ILUSTRACIJE:}

Slika 1. Geološka karta 1: 100.000 kaže na širšem območju Krnice prevladujoč vpad skladov v jugovzhodni smeri, kar je ugodno za nastanek neskladnih pobočij oziroma ostenij na nasprotni, severozahodni strani. Za razvoj doline Krnice je bil odločilen prelomni pas $\mathrm{v}$ dinarski smeri in kontakt med dolomitom in apnencem.

Fig. 1: The geological map of the valley of Krnica.

Slika 2. Kriška stena z jasno vidnimi tremi prelomi, od katerih desni kaže dislokacijo plasti. Zahodna (desna) stran je dvignjena ob prelomu in je iz karnijskega masivnega in skladnatega dolomita in apnenca, vzhodna (leva) pa je spuščena in je iz anizijskoladinijskega skladnatega dolomita in apnenca. Foto J. Kunaver.

Fig. 2: The wall of Križ or Kriška stena with the fault lines. The right one shows a rather strong displacement between the younger Karnian dolomite and limestone (the right side) and Anisian-Ladinian dolomite and limestone (the left side).

Slika 3. Pogled z vrha doline Krnice navzdol v smeri Velike Pišnice kaže izrazito ledeniško preoblikovanost. 1. Položaj srednje morene v višini med 1200 in 1300 m. 2. Čelna morena stranskega krniškega ledenika izpod Zadnjega Prisojnika. 3. Stičišče doline Krnice z dolino Velike Pišnice pri Malem Tamarju. 4. Dolomitni pomol Zadnja glava, 1765 m, pod Zadnjim Prisojnikom. 5. Položaj koče v Krnici. 6. Kranjska gora. Foto J. Kunaver.

Fig. 3: View of the glacial valley of Krnica looking downwards in the north northwestern direction.

1. The elongated morainic ridge, 2 . The terminal moraine formed by a cirque glacier, 3. The confluence of the valleys of Krnica and Velika Pišnica, 4. The dolomitic balcony of Zadnja glava, 5. The mountain hut in Krnica valley, 6. Kranjska gora.

Slika 4. Geomorfološka karta doline Krnice s sledovi poznoglacialne poledenitve.

Fig. 4: The geomorphological map of the valley of Krnica with the late glacial stadial terminal moraines. 
Slika 1/ Fig. 1

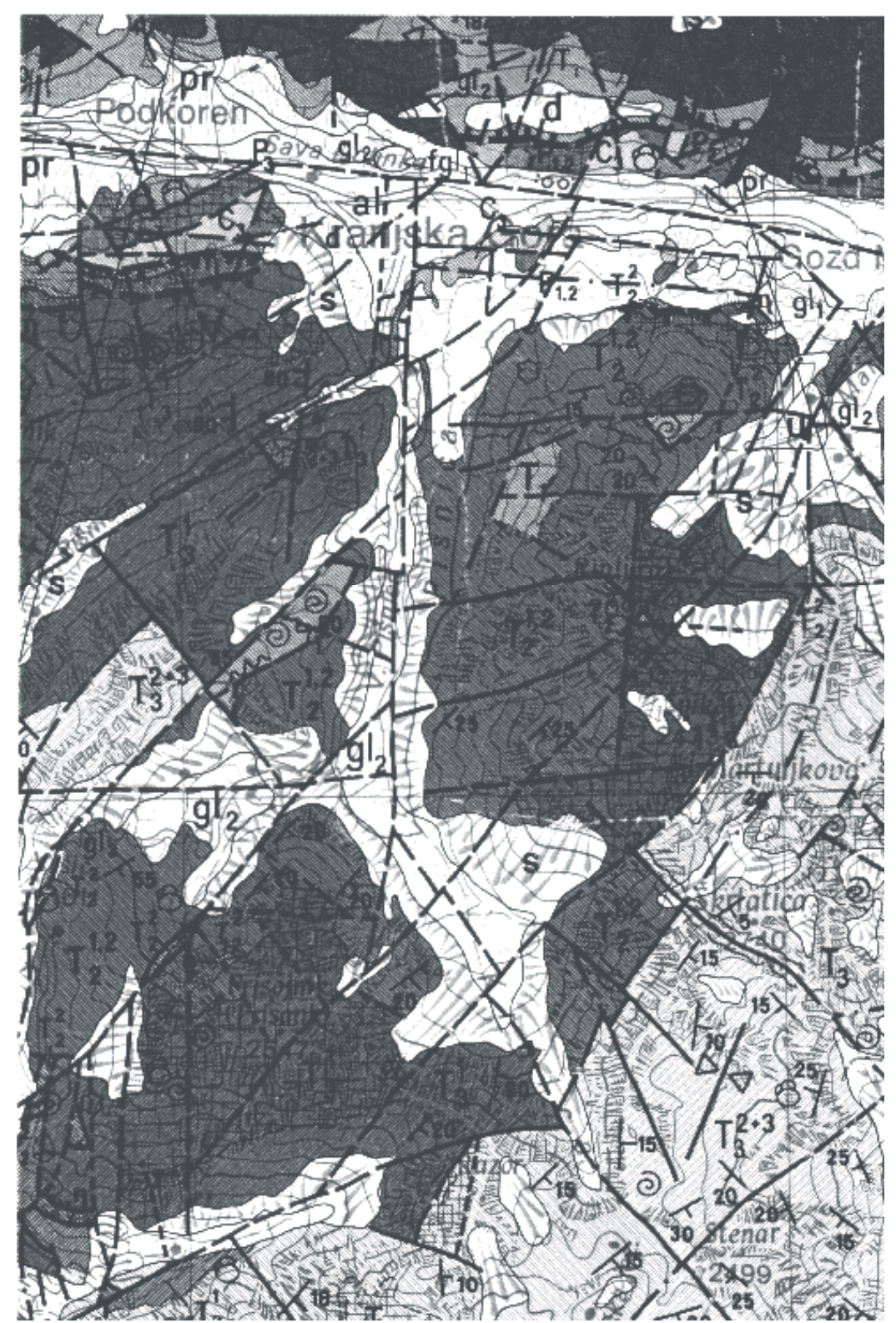


Slika 2/ Fig. 2

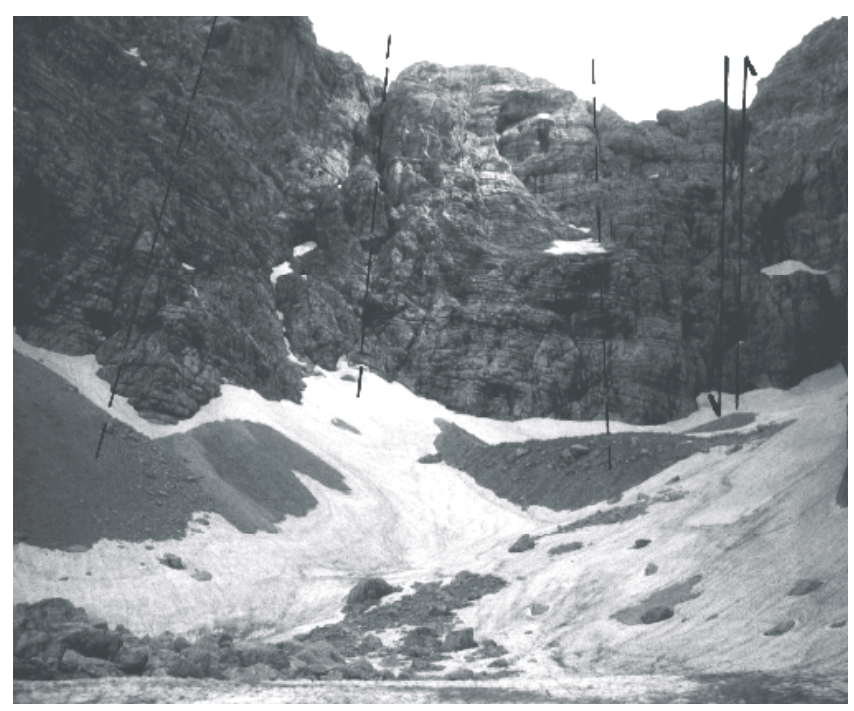

Slika 3/Fig. 3

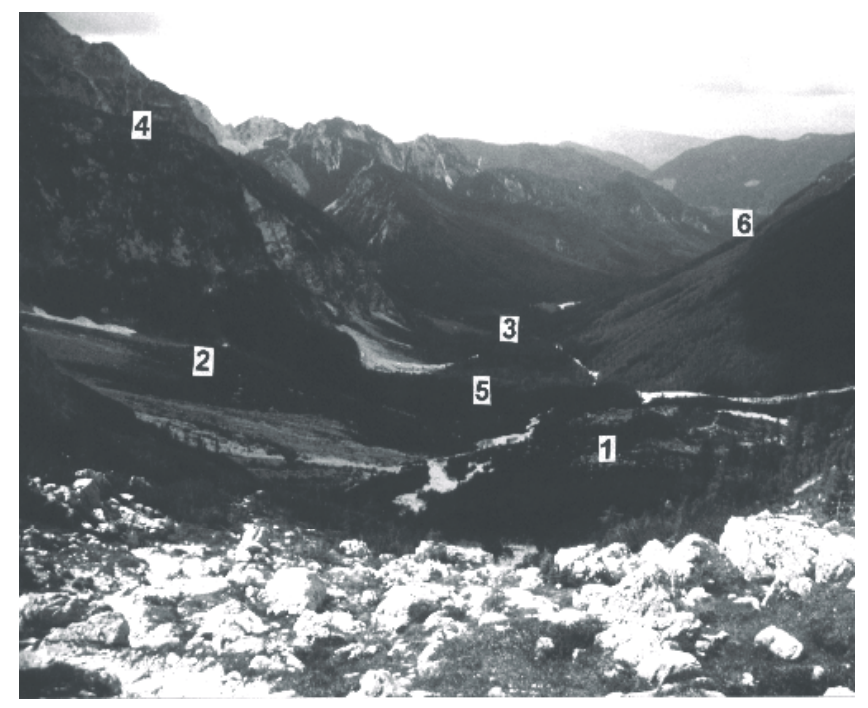


Slika 4/ Fig. 4

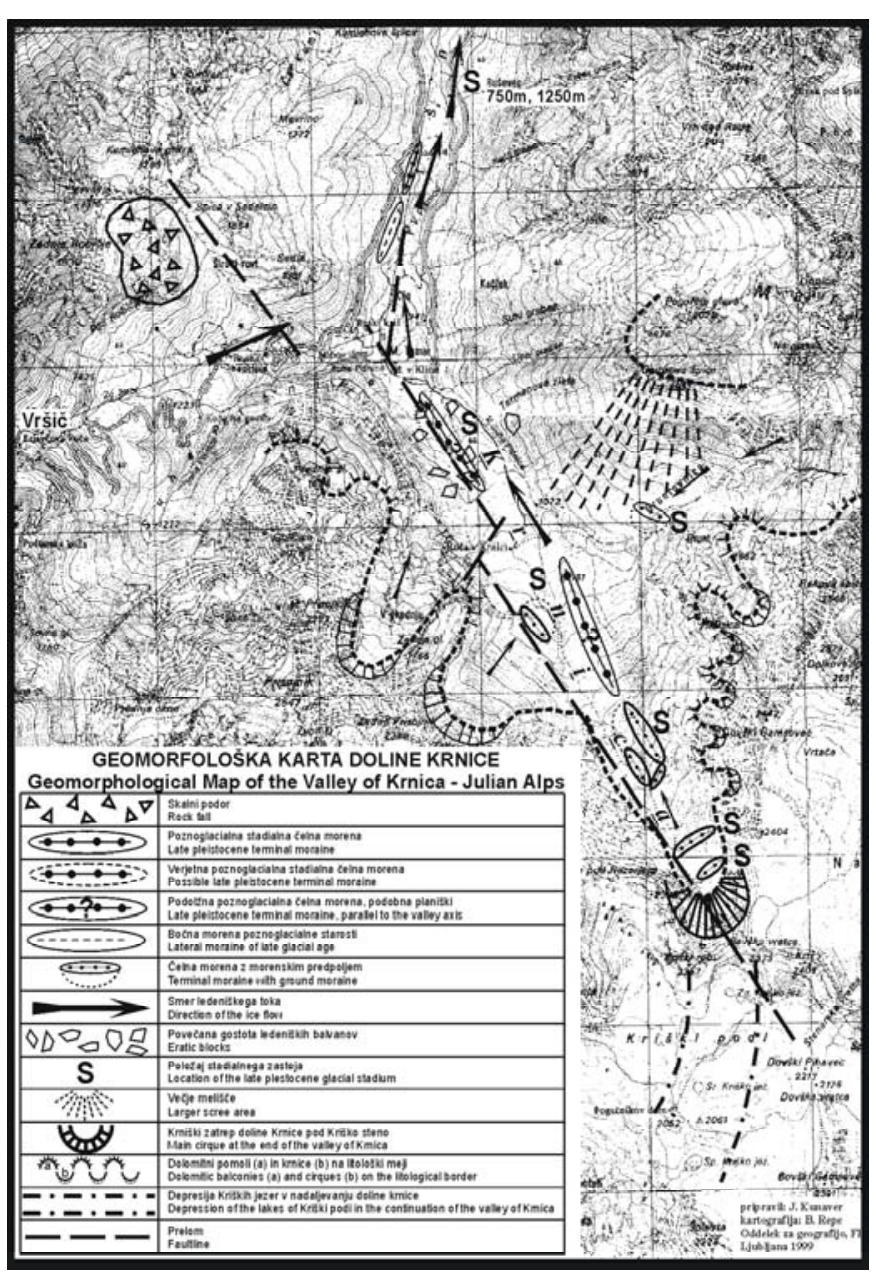

